\title{
Pendidikan Kewarganegaraan Sebagai Pendidikan Multikultural
}

\author{
Agil Nanggala \\ Pendidikan Kewarganegaraan, Universitas Pendidikan Indonesia \\ agilnanggala@upi.edu
}

\begin{abstract}
The multicultural reality of the Indonesian nation is a gift from God Almighty. This study aims to provide a rationalization, the importance of optimizing the role of civic education as a multicultural education. This research uses a qualitative approach with literary study methods, data analysis processes in the form of: data reduction, data display, verification and drawing conclusions. The results of the research obtained are: 1) Citizenship education is able to play a role as multicultural education, because the objectives and scientific structure are very supportive, especially to provide comprehensive understanding to students, so that they voluntarily maintain the nation's multiculturalism, 2) Citizenship education is able to shape the morality of students, so that consciously and fully committed to taking care of the nation's culturality, because it is a form of faith and devotion to God Almighty, as well as the real implementation of the concept of good and smart citizens.
\end{abstract}

\section{Keywords : Citizenship Education, Multiculturalism, Morality}

\begin{abstract}
Abstrak - Realita kemultikulturalan bangsa Indonesia, merupakan anugerah dari Tuhan Yang Maha Esa. Penelitian ini bertujuan untuk memberikan rasionalisasi, pentingnya mengoptimalkan peran pendidikan pendidikan kewarganegaraan sebagai pendidikan multikultural. Penelitian ini menggunakan pendekatan kualitatif dengan metode studi litertur, proses analisis data berupa: reduksi data, display data, verifikasi serta penarikan kesimpulan. Hasil penelitian yang diperoleh yaitu: 1) Pendidikan Kewarganegaraan mampu berperan sebagai pendidikan multikultural, karena tujuan dan struktur keilmuannya sangat mendukung, khususnya untuk memberikan pemahaman komprehensif kepada peserta didik, agar secara sukarela menjaga kemultikulturalan bangsa, 2) Pendidikan kewarganegaraan mampu membentuk moralitas peserta didik, agar secara sadar dan penuh komitmen untuk merawat kemultikulturalan bangsa, karena sebagai bentuk keimanan dan ketakwaannya terhadap Tuhan Yang Maha Kuasa, serta implementasi nyata dari konsep warga negara yang baik dan cerdas..
\end{abstract}

Kata kunci : Pendidikan Kewarganegaraan, Multikultural, Moralitas.

\section{PENDAHULUAN}

Realita bangsa Indonesia yang multikultural merupakan anugerah dari Tuhan Yang Maha Esa, sehingga tidak bisa diganggu gugat. Tentu fakta kemajemukan bangsa tersebut, perlu menjadi ketahanan bahkan kekuatan nasional Indonesia, dalam upaya untuk menjadi negara maju serta menjadi bangsa yang disegani. Tidak bisa dimungkiri, konflik horizontal, kekerasan SARA serta diskriminasi yang terjadi akhir-akhir ini, berpotensi untuk membawa bangsa Indonesia menuju jurang kehancurannya. Sehingga perlu adanya upaya yang terukur dan sistematis dalam menginternalisasikan pemahaman untuk hidup damai, makmur saling menyayangi, menghormati, bahkan saling melindungi, sebagai bentuk nyata dari peran warga negara yang baik dan cerdas dalam mengisi kemerdekaan bangsa Indonesia.

Konflik horizontal yang memiliki potensi negatif tersebut, pada umumnya bersifat konflik tidak produktif akibat perbedaan sikap politik pada pesta demokrasi. Tentu sebagai bangsa yang beradab kita perlu prihatin atas fenomena tersebut, karena bangsa Indonesia, dikenal dengan persatuan serta toleransinya yang kuat. Idealnya perbedaan pada pilihan politik cukuplah disikapi secara dewasa serta bijaksana, agar tidak melahirkan konflik yang tidak perlu. Jamaludin (2019: 29) menjelaskan bahwa secara sosial pemilu sangat rawan akan terjadinya konflik horizontal, 
sehingga kecerdasan masyarakat begitu diperlukan untuk mengatasi potensi konflik tersebut, dengan moralitas yang tinggi.

Nyatanya konflik horizontal yang mengancam integrasi nasional, keberagaman atau kemultikulturalan bangsa tidak selalu lahir dari perbedaan pilihan politik. Tetapi juga dari kecerdasan serta kedewasaan warga negara itu sendiri. Bangsa Indonesia memiliki karakteristik yang unik, selain percaya terhadap karunia Tuhan Yang Maha Kuasa, bangsa ini pun percaya pada semangat persatuan yang kokoh, untuk menjadi modal sosial dalam meraih kemerdekaannya, serta sebagai bekal dalam upayanya untuk menjadi negara yang berkarakter dan maju. Selaras dengan Lestari (2015: 31) yang menegaskan bahwa semangat persatuan Indonesia sebagai bangsa multikultural merupakan identitas nasional, yang harus diwariskan secara sistematis, agar Indonesia tetap eksis.

Tentu upaya dalam menjaga serta mewariskan semangat toleransi, persatuan, saling menghormati serta menyayangi, idealnya direncanakan serta dilaksanakan secara sistematis melalui pendidikan. Banyak kelebihan serta nilai positif yang bisa diperoleh, apabila mengoptimalkan peran dari eksistensi pendidikan dalam menginternalisasikan semangat tersebut. Selain dimandatkan oleh konstitusi sebagai bentuk kebijakan nasional yang berfokus pada upaya membangun manusia Indonesia yang berkarakter dan cerdas, pendidikan pun merupakan tanggung jawab seluruh warga negara Indonesia, sehingga merepresentasikan nilai-nilai persatuan dan kesatuan. Selaras dengan Charles (2017: 43) yang menegaskan bahwa tujuan pendidikan harus berorientasi pada penguatan NKRI, serta selaras dengan visi Indonesia ke depan, agar tidak tertinggal oleh kemajuan zaman.

Merujuk pada hasil sensus penduduk yang dilaksanakan oleh BPS (2011) mengungkapkan bahwa "suku bangsa Indonesia berjumlah lebih dari 1.300, dan bisa dikelompokan menjadi 31 suku bangsa". Idealnya realita keberagaman tersebut perlu disikapi secara bijaksana, dan dioptimalkan demi kebaikan bangsa, khususnya melalui pendidikan, karena berfokus pada strategi dan upaya pembangunan sumber daya manusia, agar mampu mewujudkan kedamaian, keadilan serta kesejahteraan umum. Nyatanya tujuan mulia tersebut, tersurat pada tujuan Pendidikan Kewarganegaraan, sebagaimana yang dimandatkan oleh Undang-Undang Nomor 20 Tahun 2003 Tentang Sistem Pendidikan Nasional, yang menegaskan bahwa tujuan keilmuan Pendidikan Kewarganegaraan adalah untuk "membekali peserta didik dengan pengetahuan dan kemampuan dasar yang berkenaan dengan peran warga negara serta substansi bela negara, sehingga mampu menjadi warga negara yang dapat diandalkan oleh bangsa Indonesia". Winataputra (2016: 18) mengungkapkan bahwa Pendidikan Kewarganegaraan, berfokus pada upaya holistik untuk menyelesaikan berbagai problematika kebangsaan, karena memiliki dimensi, akademik, kurikuler, sosio-kultural, termasuk pada masalah mengenai kemultikulturalan bangsa.

Pendidikan Kewarganegaraan merupakan suatu pembelajaran yang berfokus dalam membentuk warga negara Indonesia yang baik dan cerdas. Dengan tujuan mulia tersebut serta untuk menjawab kebutuhan zaman, membuat Pendidikan Kewarganegaraan menjadi keilmuan yang memiliki pendekatan interdispiliner multidispliner, bahkan transdisipliner. Selaras dengan Kariadi (2016: 18) yang menegaskan bahwa 
"pendidikan kewarganegaraan apabila ditinjau dari perspektif kurikuler pendidikan berwawasan global, serta untuk mengatasi kemajuan zaman, maka kurikulumnya perlu bersifat interdisipliner, multidispliner, serta transdisipliner". Tidak bisa dimungkiri berbagai potensi ancaman baik yang bersifat internal maupun eksternal, turut membuat kajian perkembangan ilmu dan pengetahuan di Indonesia, khususnya yang berorientasi pada pembentukan karakter warga negara, semakin dinamis dan kompleks, karena sebagai bentuk sumbangsihnya dalam menjaga keberlangsungan hidup bangsa serta meningkatkan kualitas sumber daya manusia Indonesia.

Faktanya kajian Pendidikan Kewarganegaraan sebagai pendidikan multikultural, merupakan bagian dari ilmu sosial, yang berfokus dalam mengatasi berbagai problematika yang terjadi. Khususnya berkaitan dengan kemajemukan, hak azasi manusia, demokrasi, konflik SARA, dll. Faktanya keberadaan ilmu sosial merupakan respon dari kebutuhan dasar manusia, yang tidak bisa hidup tanpa orang lain. Supriatna (2020: 130) menyatakan bahwa "ilmu sosial memiliki tujuan untuk menjawab segala fenomena, serta menyelesaikan berbagai permasalahan sosial yang terjadi”.

Merujuk dari hasil penelitian terdahulu, pada konteks optimalisasi Pendidikan Kewarganegaran sebagai pendidikan multikultural, yang dilakukan oleh Tolak (2018: 25) menyatakan bahwa "Pendidikan Kewarganegaraan pada salah satu aspek substansi keilmuannya, memuat materi kemultikulturalan, dengan orientasi peserta didik menerima secara sukarela realita bangsa Indonesia yang multikultural, sebagai upaya serta komitmen dalam menjaga keutuhan NKRI". Tentu penelitian terdahulu tersebut memiliki relevansi dengan riset yang dilakukan oleh peneliti, karena memiliki orientasi yang sama dalam upaya mengoptimalkan pendidikan kewarganegaraan sebagai pendidikan multikultural. Perbedaan mendasarnya pada ranah aspek substansi materi yang berusaha peneliti kaji, yaitu upaya membentuk moralitas siswa melalui Pendidikan Kewarganegaraan sebagai pendidikan multikultural, agar secara sukarela menerima dan menjaga realita kemajemukan bangsa. Tidak bisa dimungkiri bangsa yang bermoral dan berintergitaslah, yang akan berhasil melawan berbagai tantangan baik yang datang dari internal maupun eksternal.

Idealnya penelitian terdahulu tersebut, menjadi penguat dalam mengoptimalkan eksistensi dari Pendidikan Kewarganegaraan sebagai bentuk pendidikan dan pembelajaran multikultural. Dengan rasionalisasi bahwa Pendidikan Kewarganegaraan merupakan mata pelajaran sekaligus mata kuliah wajib bagi peserta didik, dari pendidikan dasar, menengah serta tinggi. Pendidikan Kewarganegaraan sebagai pendidikan multikutural, berfokus pada aspek materi serta substansi mengenai pentingnya menjaga keutuhan NKRI, mengutamakan persatuan dan kesatuan. Tentu upaya tersebut menjadi langkah strategis, dalam rangka memperkaya keilmuan Pendidikan Kewarganegaraan sebagai kajian kebangsaan yang komprehensif berbasiskan Ketuhanan Yang Maha Esa.

Ditinjau pada konteks teori kewarganegaraan, kita mengenal dua teori besar, yaitu teori liberal dan teori republican, yang pada era modern saat ini, terbagi menjadi tiga teori yaitu liberal, republican, dan komunitarian. Selaras dengan Hidayati (2017: 107) yang mengungkapkan bahwa teori kewarganegaraan, dapat dibagi menjadi tiga besar, yaitu liberal, republican, serta 
komunitarian. Tentu apabila ketiga teori tersebut dikaitkan dengan orientasi serta substansi pendidikan multikultural, pasti memiliki beberapa karakteristik yang mirip. Pada teori liberal, lebih menekankan hak warga negara, tentu pada pendidikan multikultural begitu mengakui hak dan kedudukan warga negara yang sama dimata hukum, pada teori republican, lebih menekankan tanggung jawab warga negara, tentu pada pendidikan multikultural memiliki orientasi dalam membentuk warga negara yang bertanggung jawab untuk menerima dan menjaga realita kemultikulturalan bangsa, pada teori komunitarian lebih berfokus pada ikatan kebersamaan, solidaritas warga negara, nyatanya pada pendidikan multikultural pun, memiliki fokus untuk mewujudkan integrasi nasional.

$$
\text { Effendi (2018: 58-59) }
$$

mengungkapkan bahwa "teori liberal lebih berfokus pada hak warga negara, teori republican lebih berfokus pada kewajiban warga negara, serta teori komunitarian lebih berfokus pada ikatan sosial warga negara". Nyatanya sebagai kajian pembelajaran, pendidikan multikultural memuat berbagai temuan, konsep, teori yang mendukung terwujudnya kehidupan multikultural di Indonesia. Rahmawati (2020: 87) menjelaskan bahwa "multikulturalisme merupakan paham serta teori yang menerima keberagaman, mengajarkan sikap toleransi, saling menghargai dan menyayangi". Tentu pada konteks keterkaitan teori kewarganegaraan serta teori multikultural bisa ditegaskan melalui substansi materinya serta orientasi pemahamannya yang memiliki kesamaan pada ranah memahami hak dan kewajiban warga negara, serta pentingnya menjaga persatuan nasional.

Idealnya realita bangsa Indonesia

yang multikultural harus menjadi peluang nasional dalam membawa bangsa Indonesia menuju puncak peradabannya. Fenomena kemajuan zaman perlu disadari serta dihadapi oleh bangsa Indonesia, maka lazimnya energi bangsa ini tidak perlu habis oleh konflik yang tidak mendewasakan. Sehingga keberadaan keilmuan Pendidikan Kewarganegaraan perlu dioptimalkan sebaik mungkin guna menghindari konflik tersebut. Dengan rasionalisasi bahwa keilmuan tersebut memiliki tujuan dalam membentuk warga negara Indonesia yang pancasilais, serta memiliki subtansi materi yang berfokus pada nilai dan sikap guna menerima, menjaga serta mendukung, realita Indonesia sebagai bangsa yang multikultural.

\section{METODE PENELITIAN}

Peneltian ini menggunakan pendekatan kualitatif, dengan metode studi literatur. Tujuan dilakukannya penelitian ini adalah untuk memberikan "rasionalisasi" mengenai pentingnya mengoptimalkan keberadaan keilmuan Pendidikan Kewarganegaraan sebagai pendidikan dan pembelajaran multikultural. Tentu dilakukannya upaya tersebut bertujuan untuk memberikan informasi argumentatif, guna menjaga persatuan dan kesatuan bangsa Indonesia. Dengan didukung oleh fakta bahwa Pendidikan Kewarganegaraan merupakan pembelajaran yang dimandatkan oleh konstitusi untuk membentuk warga negara Indonesia yang baik dan cerdas, serta paham akan hak dan kewajibannya, bahkan didukung oleh aspek materi keilmuan pendidikan kewarganegaraan yang sangat relevan untuk dioptimalkan sebagai pendidikan multikultural.

Literasi yang digunakan sebagai bahan dalam menyusun, menyelesaikan serta merefleksikan hasil penelitian ini bersumber dari jurnal serta hasil temuan 
lainnya. Tentu penggunaan jurnal sebagai sumber primer atau literasi utama, tidak lepas dari realita bahwa jurnal memiliki keabsahan yang tinggi. Temuan lain yang digunakan dalam penelitian ini, memiliki peran sebagai data sekunder atau pendukung, yang difokuskan pada sumber peraturan perundang-undangan, yang merupakan sikap nyata untuk menjaga eksistensi Indonesia sebagai negara hukum. Proses analisis data dalam penelitian ini menggunakan teknik dari Miles dan Huberman (1992) yang menjelaskan bahwa proses analisis tersebut meliputi: reduksi data, display data, verifikasi serta penarikan kesimpulan.

\section{HASIL DAN PEMBAHASAN}

\section{Peran Keilmuan Pendidikan Kewarganegaraan Dalam Membentuk Pemahaman Peserta didik Akan Pentingnya Menjaga Kemultikulturalan Bangsa.}

Sebagai konsep pembelajaran yang berfokus pada upaya peningkatan kapasitas spiritual, intelektual dan emosional peserta didik, Pendidikan Kewarganegaraan memiliki ruang lingkup kajian yang komprehensif, guna menjawab kebutuhan serta tantangan zaman. Dalam konteks subtansi materi keilmuan pendidikan kewarganegaraan, tentu pada umumnya mengarah pada kajian ideologi pancasila, bela negara, sosial dan politik, nilai dan moral, kemultikulturalan, hukum dan demokrasi, konstitusi dan ketatanegaraan, hubungan internasional, hak azasi manusia dan kebebasan pers, kebudayaan dan kearifan lokal, pertahanan dan keamanan nasional serta substansi materi lainnya yang relevan dengan tujuan serta kajian pendidikan kewarganegaraan. Diperkuat oleh (Wibowo dan Wahono, 2017: 204) yang menjelaskan bahwa "ruang lingkup atau substansi materi pada keilmuan pendidikan kewarganegaraan, berfokus pada pancasila, UUD 1945, demokrasi, nilai, etika, moral, politik, hukum, kebudayaan, kearifan lokal serta kemajemukan bangsa". Tentu substansi materi mengenai kemultikulturalan bangsa Indonesia, selain menjadi kajian penting juga sebagai modal akademik yang mampu merubah cara pandang peserta didik terhadap fenomena kemultikulturalan atau keberagaman bangsa.

Secara filosofi kemultikulturalan bangsa Indonesia merupakan anugerah dari Tuhan Yang Maha Esa, sehingga realita tersebut perlu disikapi secara bijaksana bahkan dioptimalkan sebagai upaya menjaga marwah bangsa serta membawa Indonesia menuju puncak peradabannya. We'u (2020: 74) memaparkan bahwa "kemultikulturalan bangsa Indonesia merupakan fakta sosial yang tidak terbantahkan, sehingga masyarakat harus menghargai realita tersebut dengan penuh kesadaran, guna memperkuat ikatan persaudaraan, persatuan serta saling menghargai". Nyatanya pembelajaran pendidikan kewarganegaraan memiliki peran penting dalam merubah paradigma atau cara pandang peserta didik, terhadap realita tersebut. Sehingga lumrah output dari pendidikan kewarganegaraan sebagai pendidikan multikultural adalah membentuk pemahaman peserta didik akan pentingnya menjaga keberagaman, persatuan, persaudaraan bangsa, yang didasari oleh sikap religius, nasionalisme, patriotisme, toleransi, serta saling menghargai dan menyayangi. Pendidikan kewarganegaraan sangat relevan untuk berperan sebagai pendidikan multikultural. Selain didukung oleh tujuan serta struktur keilmuannya yang mengakomodir kepentingan dalam menjaga kemultikulturalan atau kemajemukan 
bangsa, guna meminimalisir praktikpraktik yang mengarah pada kekerasan, konflik SARA, penindasan serta diskriminasi. Pendidikan kewarganegaraan pun memiliki posisi strategis dalam konstitusi serta kurikulum pendidikan nasional, yang disuratkan sebagai mata pelajaran serta mata kuliah wajib bagi peserta didik. Terlepas dari pendekatan serta strategi pembelajarannya, bahkan dari berbagai hambatan teknis yang terjadi selama proses pembelajaran atau yang terjadi di lapangan, nyatanya pendidikan kewarganegaraan telah memenuhi kriteria untuk dimandatkan sebagai pendidikan multikultural.

$$
\text { Idealnya dalam upaya }
$$

memberikan pemahaman yang

komprehensif kepada peserta didik mengenai pentingnya menjaga kemultikulturalan bangsa. Tentu perlu memenuhi ketiga aspek penting pembelajaran, yang berpusat pada ranah kognitif, afektif serta psikomotorik. Dengan orientasi memberikan pemahaman yang baik, sehingga peserta didik dengan sukarela serta penuh tanggung jawab, berperan untuk menerima serta turut menjaga realita Indonesia sebagai bangsa yang multikultural. Bukan bermaksud untuk memberikan doktrin atau dogma, yang menghilangkan sikap kritis serta pemikiran orisinil peserta didik. Tetapi untuk memberikan pemahaman yang komprehensif serta kontekstual mengenai realita keberagaman bangsa, sehingga peserta didik mampu diakomodir rasa keingintahuannya, serta bertindak sesuai pemahaman yang dimilikinya.

Faktanya

pendidikan multikultural merupakan kajian yang bertujuan untuk memberikan rasionalisasi guna menerima perbedaan sosial, khususnya yang bersifat agama, ras, budaya, serta gender, guna mewujudkan kedamaian dan keadilan, serta untuk menghindari diskriminasi, stigma negatif mengenai mayoritas dan minoritas, bahkan konflik horizontal. Dwintari (2018: 78) mengungkapkan bahwa "pendidikan kewarganegaraan berbasis multikultural merupakan kajian yang berfokus pada usaha dalam menginternalisasikan prinsip-prinsip kemultikulturalan kepada peserta didik, agar menjadi warga negara yang religius, demokratis, toleran, menghargai keberagaman serta bertanggung jawab". Nyatanya kedua konsep keilmuan tersebut, memiliki karakteristik yang mirip, khususnya pada tujuan eksplisit serta materi pembelajannya. Sehingga yang menjadi problematika serius adalah kondisi mengenai pemerataan kualitas pendidikan di Indonesia, moralitas kaum pendidik terhadap kemultikulturalan bangsa, serta kesadaran peserta didik itu sendiri.

Pada aspek kognitif, pendidikan kewarganegaraan harus mampu memenuhi rasa penarasan peserta didik terhadap konsep, pendekatan, serta makna pendidikan multikultural. Basri (2018: 1) menjelaskan bahwa "kognitif merupakan keterampilan yang berbasis otak, akal atau pikiran yang membantu peserta didik untuk menyelesaikan berbagai tugasnya dari taraf sederhana sampai yang paling kompleks". Faktanya idealisme mengenai peran keilmuan pendidikan kewarganegaraan dalam memenuhi keingintahuan peserta didik terhadap substansi serta materi kemultikulturalan sangatlah penting, karena sebagai modal akademik peserta didik untuk mengetahui, menelaah, menganalisis, bahkan mengevaluasi kebijakan pemerintah yang berkaitan dengan kemultikulturalan bangsa. Ringkasnya bagaimana peserta didik bersedia untuk menerima keberagaman, apabila mereka tidak memiliki pemahaman mumpuni secara teoritik 
mengenai kemajemukan serta tidak mengetahui praktik atau perilaku yang mendukung kemultikulturalan bangsa agar tetap terjaga.

Pada aspek afektif, lebih berfokus pada watak, nilai atau sikap, yang mana aspek tersebut sangat menentukan bagi peserta didik untuk mengaplikasikan cara pandangnya terhadap kemultikulturalan bangsa Indonesia. Dinatha (2017: 211) mengungkapkan bahwa "afektif merupakan penilaian terhadap watak serta perilaku, seperti sikap, nilai dan moral, konsep diri dan minat". Pendidikan kewarganegaraan sebagai pendidikan multikultural harus mampu merubah cara sikap serta penilaian peserta didik terhadap fenomena kemultikulturalan, tanpa paksaan, tetapi melalui penginternalisasian nilai-nilai yang sesuai dengan Pancasila dan UUD 1945, karena pada dasarnya nilai-nilai tersebut menerima serta menjaga fenomena kemajemukan bangsa. Pada konteks watak serta sikap, tentu idealnya perlu merepresentasikan nilai-nilai yang terkandung dalam Pancasila dan UUD 1945 tersebut, bukan hanya sebatas penerimaan nilai saja, tetapi juga menyentuh ranah praktis dalam kehidupan peserta didik sehari-hari.

Tidak bisa dimungkiri, suksesnya pembelajaran pendidikan kewarganegaraan sebagai pendidikan multikultural untuk memengaruhi aspek psikomotorik peserta didik, sangat tergantung pada tujuan, strategi, model serta hasil pembelajaran yang berfokus pada peningkatan kapasitas kognitif dan afektif peserta didik mengenai kemultikulturalan, karena pda subtansinya psikomotorik dalam ilmu sosial, lebih berfokus pada keahlian, kreatifitas, inovasi, menciptakan serta yang sejenisnya. Noviansah (2020: 136) mengungkapkan bahwa "psikomotorik memberikan individu yang berhubungan dengan saraf dan otot". Faktanya dengan dibekali kemampuan psikomotorik yang mumpuni, peserta didik tidak hanya memiliki pengetahuan, sikap serta nilai untuk menerima realita kemultikulturalan bangsa, tetapi juga mampu mengoprimalkan perannya sebagai generasi muda serta warga negara, melalui keterampilan, inovasi serta kreatifitasnya yang dikolaborasikan dengan kemajuan teknologi informasi dan komunikasi. Sebagai upaya untuk mendukung bangsa Indonesia yang multikultural, serta menyosialisasikan realita tersebut kepada masyarakat umum, agar meminimalisir terjadinya konflik horizontal, kesalahan persepsi, intimidasi, serta diskriminasi.

Dalam upaya menyukseskan tujuan pembelajaran pendidikan kewarganegaraan dalam membentuk mentalitas serta pemahaman peserta didik yang menerima dan menjaga kemultikulturalan, tentu perlu dipersiapkan sebaik mungkin, khususnya dalam materi serta model pembelajarannya. Materi yang dimaksudkan tersebut, pada umumya berfokus pada kajian yang membuat peserta didik paham mengenai sikap dan perilaku yang mampu menjaga kemutikulturalan, seperti: filosofi kemajemukan bangsa, kebersamaan, hubungan antar warga negara, saling menghormati, keterbukaan, sikap lapang dada dan yang lainnya. Diperkuat oleh Suparta (dalam we'u, 2020: 72) yang memaparkan bahwa "inti dari materi pembelajaran multikultural meliputi legitimasi serta makna keberagaman, pentingnya prinsip kesetaraan, saling menghormati, komitmen moral serta demokratis guna menghilangkan fenomena penindasan dan diskiriminasi". Tentu tujuan pendidikan multikultural sangat merepresentasikan cita-cita mulia bangsa Indonesia yaitu terwujudnya 
kesejahteraan umum serta keadilan sosial yang sifatnya menyeluruh.

\section{Peran Pendidikan Kewarganegaraan Sebagai Pendidikan Multikultural Dalam Membentuk Moralitas Peserta Didik.}

Indonesia sebagai bangsa religius, tentu memiliki moralitas, nilai serta etika yang diaplikasikan dalam kehidupannya sehari-hari. Baik bagi pejabat negara yang menjalankan roda organisasi pemerintahan, agar tujuan negara negara, baik secara umum maupun khusus bisa tercapai, guna memastikan keadilan, kesejahteraan serta kedamaian umum. Tentu juga bagi warga negara untuk menjalankan perannya dalam upaya mengisi kemerdekaan bangsa serta mewujudkan kepentingan umum. Moralitas begitu penting sebagai pondasi kokoh dalam memastikan bangsa ini tumbuh dan berkembang sesuai jati diri bangsanya.

Dalam upaya untuk memastikan kemultikultikulturalan bangsa tetap terjaga pun, keberadaan moralitas begitu penting. Faktanya masyarakat yang bermoral tentu akan mengutamakan kepentingan umum, seperti integrasi sosial, soliditas sosial, tidak menimbulkan perpecahan, melakukan tindakan diskriminatif, serta potensi negatif lainnya. Indonesia perlu memandang, bahwa sebagai bangsa yang memiliki keberagaman kultural, akan mudah terhasut oleh isu sensitif, seperti suku, agama, ras, antar budaya, serta gender. Sehingga begitu pentingnya untuk minimalnya menjaga sikap demi menjaga persatuan nasional, apabila terdapat permasalahan mengenai isu sensitif tersebut, tentu idealnya harus diselesaikan secara kekeluargaan, atau melalui lembaga masyarakat serta lembaga hukum.
Inanna

(2018:

mengungkapkan "pentingnya manusia Indonesia untuk memiliki moralitas yang tinggi, sebagai modal sosial dalam menjaga persatuan nasional, serta menghadapi berbagai permasalahan bangsa". Dengan memiliki moralitas yang tinggi, bangsa Indonesia mampu merefleksikan sebuah makna yang tersirat dari sebuah kejadian, khususnya yang berkaitan dengan realita kemultikulturalan. Sehingga bangsa ini tidak mudah untuk dijebak oleh oknum pada konflik horizontal serta konfik yang tidak mendewasakan. Moralitas pun menjadi bukti kuat, bangsa Indonesia masih menjadi bangsa yang percaya terhadap Tuhan Yang Maha Esa, dengan begitu kekuatan Tuhan akan selalu melindungi serta menyelamatkan Indonesia dari jurang kehancurannya, seperti saat kemerdekaan bangsa 1945, pemberontakan tahun 1966, krisis moneter 1998 dan kejadian yang lainnya.

Nilai, moral serta etika yang sesuai dengan kepribadian bangsa Indonesia, perlu diinternalisasikan kepada peserta didik, melalui pendidikan kewarganegaraan sebagai pendidikan multikultural. Tentu kita tidak berharap, Indonesia kehilangan calon penerusnya yang berkompeten, berkarakter dan unggul, sehingga harus dipersiapkan sebaik mungkin. Sehingga realita Indonesia sebagai bangsa yang multikultural, perlu untuk diwariskan secara berkesinambungan, sebagai bentuk gerakan moral secara sukarela dan penuh komitmen, karena diyakini nilai kebenaran serta nilai kebermanfaatannya oleh peserta didik. Diperkuat Fathurrosi (2018: 155) yang memaparkan bahwa pada dasarnya nilainilai yang diyakini kebenarannya oleh masyarakat, akan selalu diamalkan serta diwariskan pada generasi selanjutnya, seperti nilai-nilai Pancasila yang hidup dalam masyarakat Indonesia. 
Tentu eksistensi dari Pendidikan Kewarganegaraan sebagai pendidikan multikultural, perlu dioptimalkan sebaik mungkin, khususnya dalam upaya membentuk moralitas peserta didik. Dengan rasionalisasi, struktur keilmuan pendidikan kewarganegaraan sangat mendukung dalam upaya mewujudkan tujuan tersebut, karena pendidikan kewarganegaraan memiliki fokus kajian yang umum, yaitu ideologi Pancasila serta nilai dan moral. Sehingga tidak jarang apabila pendidikan kewarganegaraan selalu diidentikan sebagai pendidikan karakter, atau pendidikan nilai dan moral, karena pada hakikat tujuannya, yaitu mempersiapkan peserta didik untuk menjadi warga negara yang baik dan cerdas, sehingga mampu memahami hak dan kewajibannya, serta dapat diandalkan oleh negara. Dwintari (2017: 21) menegaskan pendidikan kewarganegaraan merupakan pendidikan karakter, karena memiliki tujuan dalam membentuk karakter peserta didik yang pancasilais, seperti percaya terhadap Tuhan Yang Maha Esa, adil serta beradab, menjaga persatuan, demokratis, serta membantu negara dalam mewujudkan keadilan sosial.

Dalam kapasitasnya sebagai pendidikan nilai dan moral, pendidikan kewarganegaraan memiliki kompetensi mumpuni dalam menginternalisasikan nilai-nilai Pancasila kepada peserta didik, serta membentuk moralitas peserta didik yang memiliki semangat kepahlawanan. Moralitas yang dicita-citakan melalui pembelajaran pendidikan kewarganegaraan sebagai pendidikan multikultural adalah mampu membentuk peserta didik yang mengutamakan integrasi nasional, menjaga kedamaian masyarakat, serta melestarikan nilai dan budaya yang hidup di lingkugan sekitarnya. Pendidikan kewarganegaraan sebagai pembelajaran moral, tentu percaya adanya kekuasaan Tuhan Yang Maha Esa, sehingga pembelajaran tersebut memiliki orientasi dalam membentuk peserta didik yang beriman dan bertakwa kepada Tuhan Yang Maha Esa, tentu dengan peserta didik yang memiliki kapasitas keimanan dan ketakwaan yang baik, akan menerima realita kemultikulturalan bangsa, karena menandakan anugerah serta kebesaran Tuhan Yang Maha Kuasa. Nanggala (2020: 19) mengungkapkan bahwa merupakan kodratnya Indonesia untuk menjadi bangsa yang multikultural, sehingga pendidikan kewarganegaraan perlu memberikan teori dan landasan filosofis, etis, yuridis, serta sosiologis agar keadilan serta kedamaian bisa terwujud dalam kehidupan masyarakat multikultural.

Suharno

(2016:

164)

mengungkapkan bahwa pendidikan kewarganegaraan merupakan pendidikan nilai dan moral, karena substansi materinya yang relevan serta tujuannya dalam membentuk warga negara yang berkarakter Pancasila. Tentu dalam upaya mengoptimalkan pendidikan kewarganegaraan sebagai pendidikan nilai dan moral, agar peserta didik secara sukarela menerima realita kemajemukan bangsa, idealnya perlu menerapkan konsep pembelajaran kontekstual. Nyatanya banyak kelebihan yang bisa didapat apabila mengaplikasikan konsep pembelajaran tersebut, selain efektif, karena memberikan pemahaman komprehensif mengenai kemultikulturalan bangsa kepada peserta didik, juga menyenangkan, bahkan mengakomodir siswa untuk melatih daya kreatifitasnya. Pendidikan multikultural tentu bisa dikolaborasikan dengan pembelajaran kontekstual melalui tahapan, sebagai berikut: 1) memberikan pijakan filosofis yang kuat, 2) pengintegrasian teori 
kemultikulturalan dengan berbagai teori ilmu sosial serta tujuan pembelajaran kontekstual, 3) menerapkan strategi pembelajaran yang mendukung, serta 4) mengindetifikasi keanekaragam budaya Indonesia sebagai sumber pembelajaran kontekstual (Warpala, 2019: 23)

Faktanya membentuk peserta didik yang bermoral tidaklah mudah, karena merupakan proses investasi manusia Indonesia yang beradab, sehingga perlunya peran nyata dari setiap guru, khususnya guru pendidikan kewarganegaraan sebagai pendidikan multikultural, harus mampu membentuk peserta didik yang pancasilais. Tentu peserta didik yang pancasilais merupakan representasi dari peserta didik yang memiiki kapasitas mumpuni pada ranah spiritual, intelektual, dan emosional, pada konteks menerima serta menjaga kemultikulturalan bangsa, tentu setiap guru perlu memahami realita tersebut, sehingga dengan sukarela untuk mentransformasikan pemahaman tersebut kepada peserta didik. Bukan bersifat pembelajaran satu arah, yang berpotensi menghalangi hak peserta didik untuk bertanya, berpikir, bertindak serta menghayati, tetapi sebagai upaya dalam memberikan pemahaman yang komprehensif, melalui akal pikiran, serta secara emosional, sehingga peserta didik mampu mengambil pelajaran berharga dari realita tersebut. Peran guru secara eksplisit dalam pendidikan multikultural yaitu: 1) membangun paradigma kemultikulturalan, 2) membangun sikap menghargai kemultikulturalan, 3) membangun sikap peduli sosial, 4) membangun sikap anti diskriminasi terhadap etnis, serta 5) membangun sikap anti diskriminasi terhadap kemampuan (Kusnadi dan Assa'diyah, 2020: 6-8)

Peran guru, khususnya mata pelajaran dan mata kuliah PKn sangatlah penting dalam membentuk moralitas siswa, agar secara sukarela menerima dan menjaga kondisi Indonesia sebagai bangsa yang multikultural. Dengan rasionalisasi tersebut, membuat setip guru untuk tetap menjaga integritas dan kesetiaannya terhadap pada Pancasila, UUD 1945, NKRI serta Bhinneka Tunggal Ika. Widiyono (2018: 290) menegaskan bahwa "guru memiliki peran viral dalam menyukseskan pembelajaran pendidikan multikultural, karena keberadaanya mampu membuat siswa memahami makna demokrasi, HAM, keadilan dan kemajemukan, sehingga melahirkan peserta didik yang cinta damai, menjauhi praktik-praktik penindasan dan diskriminasi”. Nyatanya, dengan moralitas yang tinggi, membuat setiap masyarakat Indonesia menerapkan budaya toleransi, saling menghormati serta menghargai, sehingga mampu meminimalisir timbulnya resistensi akibat isu yang berkaitan dengan disintegrasi sosial. Dinamika perkembangan keilmuan pendidikan kewarganegaraan yang perlu menyesuaikan dengan kemajuan serta kebutuhan zaman, nyatanya tidak merubah kebutuhan serta substansi dasar, dari tujuan keilmuannya, guna membentuk peserta didik yang Pancasilais. Tentu sebagai pendidikan nilai dan moral, pendidikan kewarganegaraan perlu memberikan pemahaman komprehensif serta informasi argumentatif mengenai pentingnya menerima serta merawat kemultikulturalan bangsa. Sebagai pembelajaran yang berorientasi pada penginternalisasian nilai-nilai Ketuhanan dan kemanusiaan kepada peserta didik, pendidikan kewarganegaraan memiliki peran penting dalam menjaga persatuan dan kesatuan bangsa Indonesia, serta membawa bangsa ini menuju puncak peradabannya. Menerima serta merawat kemultikulturalah bangsa, bahkan turut 
berpartisipasi aktif dalam mewujudkan kedamaian dan menjaga integrasi nasional merupakan bukti dari implementasi konsep warga negara yang bermoral, bahkan menjadi bentuk rasa syukur terhadap Tuhan Yang Maha Esa.

\section{KESIMPULAN DAN SARAN}

Realita Indonesia sebagai bangsa yang multikultural merupakan anugerah dari Tuhan Yang Maha Esa, sehingga kita perlu menerima bahkan merawat kemultikulturalan tersebut dengan penuh komitmen dan kesadaran. Tentu sikap tersebut membuktikan keimanan dan ketakwaan kita terhadap Tuhan Yang Maha Kuasa, serta merepresentasikan warga negara yang baik dan cerdas. Pendidikan kewarganegaraan sangat relevan untuk berperan sebagai pendidikan multikultural. Selain didukung oleh tujuan serta struktur keilmuannya yang jelas berfokus pada upaya untuk menjaga kemultikulturalan atau kemajemukan bangsa, guna meminimalisir praktik-praktik yang mengarah pada ketidakadilan, kekerasan, konflik horizontal, penindasan serta diskriminasi.

Pendidikan kewarganegaraan sebagai pendidikan multikultural pun memberikan landasan teori serta informasi argumentatif agar peserta didik memiliki pemahaman mumpuni mengenai filosofi, substansi serta pentingnya menjaga kemultikulturalan bangsa. Sehingga secara sukarela mengaplikasikan pemahamannya tersebut dalam kehidupan sehari-hari peserta didik. Dalam kapasitasnya sebagai pendidikan nilai dan moral, pendidikan kewarganegaraan memiliki orientasi serta kompetensi keilmuan yang mumpuni untuk menginternalisasikan nilai-nilai terpuji kepada peserta didik, serta membentuk moralitasnya, sehingga memiliki semangat yang merepresentasikan nilai- nilai Pancasila dan UUD 1945. Moralitas yang dicita-citakan melalui pembelajaran pendidikan kewarganegaraan sebagai pendidikan multikultural adalah mampu membentuk peserta didik yang mengutamakan integrasi nasional, menjaga kedamaian masyarakat, serta melestarikan nilai dan budaya yang hidup dimasyarakat.

Merujuk pada kesimpulan yang dideskripsikan di atas, tentu idealnya berbagai temuan, konsep, teori yang berkaitan dengan perkembangan ilmu dan pengetahuan, perlu diterapkan pada kehidupan masyarakat, karena demi menyelesaikan problematika kompleks, khususnya yang mengarah pada ketidakadilan, konflik horizontal, serta belum terwujudnya kesejahteraan umum. Termasuk pada kajian pendidikan kewarganegaraa sebagai pendidikan multikultural, yang berfokus pada temuan serta subtansi materinya yang berikan rasionalisasi, serta ulasan positif mengapa perlu menerima realita kemultikulturalan, yang diejawantahkan melalui sikap yang menjaga kemultikulturalan tersebut. Tentu pemangku kebijakan serta akademisi memiliki peran penting dalam menjaga kemultikultikulturalan bangsa. Pemangku kebijakan atau pemerintah yang dimandatkan oleh masyarakat untuk mewujudkan keadilan sosial, pada konteks mendukung terselenggaranya kehidupan yang multikultural,

Nyatanya pemerintah perlu memiliki skema serta program kerja yang jelas, khususnya yang berfokus pada upaya pencerdasan masyarakat, pemenuhan hak warga negara, mengurangi kesenjangan sosial dan ekonomi masyarakat, meminimalisir konflik SARA, serta penegakan HAM, agar terwujudnya kehidupan yang religius, demokratis serta modern dalam kehidupan bangsa Indonesia. Tidak bisa dimungkiri, peran akademisi sangatlah 
penting dalam menjaga kemultikulturalan, khususnya pada aspek dalam menemuka temuan, konsep, serta teori yang relevan, dalam memberikan informasi argumentatif, untuk menerima dan menjaga kemultikulturalan bangsa. Penelitian pada jurnal ini yang berfokus pada upaya memberikan rasionalisasi informatif, mengenai urgensi pendidikan kewarganegaraan untuk dioptimalkan sebagai pendidikan multikultural, karena struktur keilmuanya serta posisinya pada kurikulum nasional sangat mendukung. Sehingga idealnya peneliti selanjutnya perlu melakukan berbagai riset yang berkaitan dengan kemultikulturalan bangsa, untuk menemukan temuan serta konsep yang komprehensif, serta mengkaji secara filosofis, apakah kajian pendidikan multikultural, berpeluang untuk menjadi disiplin ilmu, atau tidak, karena begitu berpengaruh terhadap dinamika perkembangan keilmuan nasional yang merepresentasikan nilainilai Pancasila dan UUD 1945.

\section{DAFTAR PUSTAKA}

Badan Pusat Statistik. (2011). Kewarganegaraan, Suku Bangsa, Agama, dan Bahasa Sehari-hari Penduduk Indonesia. Jakarta: BPS.

Basri, H. (2018). Kemampuan Kognitif dalam Meningkatkan Efektivitas Pembelajaran Ilmu Sosial bagi Siswa Sekolah Dasar. Jurnal Penelitian Pendidikan. 18 (1). Hlm. 1-9.

Charles. (2017). Pendidikan Multikultural untuk Memperkuat Kohesifitas Persatuan dan Kesatuan Bangsa. Jurnal Educative: Journal of Educational Studies. 2 (1). Hlm. 30-46.
Dinatha, N. M. D. (2017). Pemanfaatan Media Sosial Facebook untuk Menilai Sikap Ilmiah (Afektif) Mahasiswa. Journal of Education Technology. 1 (3). Hlm. 211-217.

Dwintari, J. W. (2017). Kompetensi Kepribadian Guru dalam Pembelajaran Pendidikan Kewarganegaraan Berbasis Penguatan Pendidikan Karakter. Jurnal Pendidikan Kewarganegaraan. 7 (2). Hlm. 51-57.

Dwintari, J. W. (2018). Urgensi Pendidikan Kewarganegaraan Berbasis Multikultural dalam Pembinaan Keberagaman Masyarakat Indonesia. CivicCulture: Jurnal Ilmu Pendidikan PKn dan Sosial Budaya. 2 (1). Hlm. 69-81.

Effendi, W. R. (2018). Konsepsi Kewarganegaraan dalam Perspektif Tradisi Liberal dan Republikan. Jurnal Trias Politica. 2 (1). Hlm. 55-62.

Fathurrosi. (2018). Kesaktian Pancasila dalam Membangun Kesadaran dan Keamanan Bangsa Indonesia. Nizham Journal of Islamic Studies. 6 (1). 115-129.

Hidayah, H. (2017). Partisipasi Masyarakat dalam Membangun Civic Virtue di Desa Balun Kecamatan Turi Kabupaten Lamongan. Jurnal Kajian Moral dan Kewarganegaraan. 5 (1). 106-120.

Inanna. (2018). Peran Pendidikan dalam Membangun Karakter Bangsa yang Bermoral. JEKPEND Jurnal Ekonomi dan Pendidikan. 1 (1). Hlm. 27-33.

Jamaludin, T. (2019). Pilkada Langung: Kisah Sukses dan Problematika. Jurnal Politik Walisongo. 1 (1). Hlm. 29-48. 
Kariadi, D. (2016). Revitalisasi NilaiNilai Edukatif Pendidikan Kewarganegaraan untuk Membangun Masyarakat Berwawasan Global Berjiwa Nasionalis. Jurnal PIPSI: Jurnal Pendidikan Ilmu Pengetahuan Sosial Indonesia. 1 (1). Hlm. 1423.

Kusnadi, A. \& Assa'diyah, F. (2020). Peran Guru Pendidikan Agama Islam dalam Mengimplementasikan

Pendidikan Multikultural Berbasis Nilai-Nilai Pendidikan Islam di Sekolah Menengah Pertama (SMP) Nasional Plus Tunas Global Kota Depok. Jurnal Al-Qalam: Jurnal Pendidikan dan Keislaman. 8 (1). Hlm. 1-18.

Lestari, G. (2015). Bhinnekha Tunggal Ika: Khasanah Multikultural Indonesia di Tengah Kehidupan SARA. Jurnal Pendidikan Pancasila dan Kewarganegaraan. 28 (1). Hlm. 31-37.

Miles, M. B., \& Huberman, A. M. (1992). Analisis data kualitatif: buku sumber tentang metodemetode baru. Jakarta: Universitas Indonesia Press.

Nanggala, A. (2020). Memaknai Keadilan Berdasarkan Ketuhanan Yang Maha Esa Ditunjau dari Perspektif Pendidikan Kewarganegaraan. Jurnal Widya Wacana. 15 (1). Hlm. 16-22.

Noviansah, A. (2020). Objek Assesment, Pengetahuan, Sikap, dan Keterampilan. Al-Hikmah: Jurnal Studi Islam. 1 (2). Hlm. 136-149.

Rahmawati, T. N. (2020). Peluang Mata Pelajaran Ilmu Pengetahuan Sosial (IPS) dalam Mewujudkan Pendidikan yang Berbasis
Multikultural. Jurnal Soshum Insentif. 3 (1). Hlm. 86-91.

Suharno. (2016). Pengembangan Aspek Moral dalam Pendidikan Kewarganegaraan SD dan SMP: Respons atas Realitas Keprihatinan Moral. Jurnal Civics. 13 (2). Hlm. 162-171.

Supriatna, E. (2019). Islam dan Pengetahuan. Jurnal Soshum Insentif. 2 (1). Hlm. 128-135.

Tolak, T. (2018). Peneguhan Masyarakat Multikultural Indonesia melalui Aktualisasi Pendidikan Pancasila dan Kewarganegaraan. JUPIIS: Jurnal Pendidikan Ilmu-Ilmu Sosial. 10 (2). Hlm. 21-30.

Undang-Undang Nomor 20 Tahun 2003 Tentang Sistem Pendidikan Nasional.

Warpala, I. W. S. (2019). Pembelajaran Kontekstual: Sebuah Inovasi Penerapan Pendidikan Multikultural dan Belajar untuk Penemuan. Media Edukasi: Jurnal Ilmu Pendidikan, 3 (1). Hlm. 21-27.

We'u, G. (2020). Urgensi Pendidikan Multikultural: sebuah Jawaban atas Problematika Pluralitas. JIPD: Jurnal Inovasi Pendidikan Dasar. 4 (2). Hlm. 71-75.

Wibowo, A. P. \& Wahono, M. (2017). Pendidikan Kewarganegaraan: Usaha Konkret untuk Memperkuat Multikulturalisme di Indonesia. Jurnal Civicus. 14 (2). Hlm. 198-202.

Widiyono, S. (2018). Peran Guru dalam Mengimplementasikan

Pendidikan Multikultural. Elementary School: Jurnal Pendidikan dan Pembelajaran ke-SD-an. 5 (2). Hlm. 282-290.

Winataputra, U. Winataputra, U. S. (2016). Posisi Akademik Pendidikan Kewarganegaraan (Pkn) dan Muatan/Mata 
210 | Agil Nanggala

Pelajaran Pendidikan Pancasila

dan Kewarganegaraan (PPkn)

dalam Konteks Sistem

Pendidikan Nasional. Jurnal

Moral Kemasyarakatan, 1(1).

Hlm. 15-36. 